\title{
Medication errors: classification of seriousness, type, and of medications involved in the reports from a University Teaching Hospital
}

\author{
Gabriella Rejane dos Santos Dalmolin ${ }^{1, *}$, Eloni Terezinha Rotta², José Roberto Goldim¹,3
}

${ }^{1}$ Research Laboratory in Bioethics and Research Ethics, Hospital de Clínicas de Porto Alegre, Porto Alegre, RS, Brazil, ${ }^{2}$ Pharmaceutical Service/Hospital de Clínicas de Porto Alegre, Porto Alegre, RS, Brazil, ${ }^{3}$ Bioethics Service/Hospital de Clínicas de Porto Alegre, Porto Alegre, RS, Brazil

\begin{abstract}
Medication errors can be frequent in hospitals; these errors are multidisciplinary and occur at various stages of the drug therapy. The present study evaluated the seriousness, the type and the drugs involved in medication errors reported at the Hospital de Clínicas de Porto Alegre. We analyzed written error reports for 2010-2011. The sample consisted of 165 reports. The errors identified were classified according to seriousness, type and pharmacological class. 114 reports were categorized as actual errors (medication errors) and 51 reports were categorized as potential errors. There were more medication error reports in 2011 compared to 2010 , but there was no significant change in the seriousness of the reports. The most common type of error was prescribing error (48.25\%). Errors that occurred during the process of drug therapy sometimes generated additional medication errors. In 114 reports of medication errors identified, 122 drugs were cited. The reflection on medication errors, the possibility of harm resulting from these errors, and the methods for error identification and evaluation should include a broad perspective of the aspects involved in the occurrence of errors. Patient safety depends on the process of communication involving errors, on the proper recording of information, and on the monitoring itself.
\end{abstract}

Uniterms: Medication/errors. Drug therapy. Patients/safety.

Erros envolvendo medicamentos ocorrem frequentemente em hospitais, possuem natureza multidisciplinar e podem ocorrer nas várias etapas da terapia medicamentosa. O estudo avaliou a seriedade, o tipo e os medicamentos envolvidos nos erros de medicação notificados no Hospital de Clínicas de Porto Alegre. Foram analisadas notificações de erros realizadas por escrito em 2010-2011. A amostra foi composta por 165 notificações. Cento e catorze notificações foram classificadas como erros de fato (erros de medicação) e 51 notificações, como erros potenciais. Apesar de se ter realizado maior número de notificações de erros de medicação em 2011, comparativamente a 2010, não houve alteração significativa no perfil de seriedade destes eventos. O tipo de erro mais frequente foi o de prescrição (48,25\%). Os erros ocorridos ao longo do processo geraram, em algumas situações, novos erros de medicação associados. Nas 114 notificações de erros de medicação identificadas citaram-se 122 medicamentos. A reflexão sobre os erros de medicação e a possibilidade de danos decorrentes dos mesmos, assim como dos métodos para a sua identificação e avaliação, deve incluir uma ampla perspectiva dos aspectos envolvidos na sua ocorrência. A segurança dos pacientes depende deste processo de comunicação, do registro adequado das informações e do monitoramento propriamente dito.

Unitermos: Medicação/erros. Terapia medicamentosa. Pacientes/segurança.

*Correspondence: G. R. S. Dalmolin. LAPEBEC/HCPA, Laboratório 12213. Rua Ramiro Barcelos, 2350, 90035-903 - Porto Alegre - RS, Brasil. E-mail: dalmolingabriella@gmail.com 


\section{INTRODUCTION}

The healthcare system is extremely complex. It involves critical situations of risk, an interaction between multiple professionals and institutions, and depends on significant support from technology. The characteristics of the system may heighten the risk of mistakes and worsen the consequences of these mistakes. In this sense, it is important to assess risk and damage to patients in the search for ultimate patient safety (Rosa, Perini, 2003). The World Health Organization definition of patient safety establishes that unnecessary harm or potential harm associated with healthcare should be reduced to an acceptable minimum (WHO, 2009).

Medication errors may be defined as any preventable event that may cause or lead to inappropriate medication use or patient harm while the medication is in the control of the healthcare professional, patient, or consumer. The error may be related to professional practice, to healthcare products, to procedures, to communication problems (including prescribing, product labeling, packaging, and nomenclature), to compounding, to dispensing, to distribution, to administration, to education, to monitoring, and to the proper use of medications (NCCMERP, 2001a).

International studies have established that the medication error rate varies from 1.5 to $35.0 \%$ depending on several factors. These factors include type of classification, method of error identification, and the common denominator adopted (Otero et al., 2008). According to Wannmacher (2005), recognizing errors is the best way to improve the quality and safety of healthcare activities.

Usually, medication errors are detected only if there are clinical consequences manifested by the patient, such as the presence of symptoms sometime after the administration of the medication, thus alerting the healthcare professionals (Carvalho, Cassiani, 2002). The clinical consequences of the error may be confounded with adverse reactions to medication, but medication errors are different from adverse drug reactions. According to the World Health Organization (WHO, 1972), an adverse reaction is any harmful or undesirable effect presented after administration of medication at doses normally used for prophylaxis, diagnosis, or treatment of diseases. It is not possible to prevent adverse reactions, even though the possibility of an adverse reaction is known.

The possibility that predictable harm may occur results in the need for establishing adequate prevention measures. The Precautionary Principle established by Hans Jonas (1994) is based on the Ethics of Responsibility. Healthcare professionals are always responsible for any action they carry out, but this does not imply in guilt by association. In this sense, Bioethics may help develop an adequate understanding of the need to establish contingency measures for predictable risks.

The implementation of systems for the detection and prevention of medication errors must be one of the pharmacovigilance goals at healthcare institutions. Nunes and colleagues (2008) underscored the need for systematic and continuous evaluation to decrease the incidence of errors and contribute to the identification and report of new error possibilities, which, in turn may have been mistakenly categorized as adverse drug reactions. These systems may also contribute to the identification of occurrences that would normally be kept secret (Nunes et al., 2008).

Spontaneous reporting, chart review, review of medical prescriptions, and direct observation are the main methods for identification and evaluation of medication errors (Coimbra, 2006). Each method has its advantages and disadvantages; the methods adopted should be adapted to institutional goals and used as management tools for healthcare quality improvement (Bohomol, Ramos, 2007).

During the process of implementation of an institutional program of pharmacovigilance, the methods may be implemented progressively. Spontaneous reporting may be the method of choice for an initial stage; it allows for the participation of all sectors of the institution and for the implementation of a more autonomous culture of error checking and evaluation. Other more direct methods may be interpreted by healthcare professionals as external evaluation measures.

In Brazil, there has been increasing interest and discussions about medication errors. However, the studies that have been published have issues that need to be addressed; these issues involve conceptual clarity, geographical distribution, professional perspective, and the focus of ethical aspects involved. In relation to conceptual clarity, first, there were studies that reported adverse events, adverse drug reactions, and medication errors indistinctly (Rissato et al., 2008). In relation to geographical distribution, there is a predominance of studies carried out in southeastern Brazil, especially São Paulo (Optiz, 2006). Almost all studies adopt the point of view of nursing professionals (Telles Filho, Praxedes, 2009). Also, few Brazilian studies have addressed either the ethical aspects involved in medication errors or the most adequate way to address these situations (Coli et al., 2010).

The aim of the present study was to evaluate the seriousness, the type, and the medications involved in medication errors reported at the Hospital de Clínicas de Porto Alegre in 2010 and 2011. 


\section{METHOD}

The study was carried out at Hospital de Clínicas de Porto Alegre (HCPA). The HCPA is a general teaching hospital with a hospital bed capacity of 795 , which are divided in 18 conventional inpatient units, five intensive care units, and the adults and children emergency units.

We carried out a retrospective, cross-sectional study to evaluate the medication error reports, submitted in written form to the Group for Safe Use of Medications (GUS, in Portuguese) at the HCPA, from January 2010 to December 2011. The Group is constituted by representatives from the Medications Committee, Pharmaceutical Service, and Nursing Group. This group analyzes the error reports submitted through the voluntary reporting system at the HCPA. We excluded reports that did not have enough information for their correct categorization, the reports that were duplicated, and the reports that were made after the period investigated (even though they refer to an event that happened during the period). The study sample included 165 spontaneous error reports.

We carried out a survey of the GUS files with the aim of identifying in reports actual errors (medication errors) and potential errors (circumstances or events that may lead to errors). The medication errors identified were classified according to seriousness, type, and pharmacological class.

Seriousness was categorized using nine different categories, from A to I. The classification includes occurrence of an error; if the error reached the patient, or not; the harm associated with the error; and the necessary measures (Figure 1). The classification was based on the National Coordinating Council for Medication
Error Reporting and Prevention Error Category Index (NCCMERP, 2001b).

The reports categorized as errors that actually occurred (category B-I) were also categorized as for the type of error according to the American Society of HealthSystem Pharmacists (ASHP). The ASHP classifies errors as prescribing error, dispensing error, omission error, wrong time error, unauthorized drug error, improper dose error, wrong dosage-form error, wrong drug-preparation error, wrong administration-technique error, deteriorated drug error, monitoring error, compliance error, and other medication error (ASHP, 1993).

We carried out the pharmacological classification of drugs involved in errors. We used the Anatomical Therapeutic Chemical Classification System of the WHO Collaborating Centre for Drug Statistics Methodology. The drugs can be classified into five different levels according to: anatomical main group (first level), therapeutic main group (second level), therapeutic/ pharmacological subgroup (third level), chemical/ therapeutic/pharmacological subgroup (fourth level), and the chemical substance (fifth level) (WHO, 2012).

Statistical analyses were carried out to verify the frequency and association distributions between the variables. We used the chi-square test to evaluate the associations (using EPI INFO software, version 3.5.2). The level of significance was set at $5 \%(\mathrm{P}=0.05)$.

In order to evaluate mistakes in the process of reporting medication errors, we also evaluated the reports of adverse drug reactions submitted to the Pharmaceutical Service at the HCPA in 2011.

The study was approved by the Ethics Committee of the HCPA (project number 10-0445). The researchers

\begin{tabular}{|c|c|c|c|c|}
\hline Error category & Error occurrence & $\begin{array}{c}\text { Reached } \\
\text { patient }\end{array}$ & $\begin{array}{c}\text { Associated } \\
\text { harm }\end{array}$ & Necessary measures \\
\hline A & Potential & No & No & No \\
\hline B & Yes & No & No & No \\
\hline C & Yes & Yes & No & Monitoring \\
\hline D & Yes & Yes & No & Medical intervention \\
\hline E & Yes & Yes & Temporary & $\begin{array}{c}\text { Hospitalization or } \\
\text { prolonging hospital stay }\end{array}$ \\
\hline F & Yes & Yes & Temporary & Variable \\
\hline G & Yes & Yes & Permanent & - \\
\hline H & Yes & Yes & Risk of death & Vital support intervention \\
\hline I & Yes & Yes & Death & \\
\hline
\end{tabular}

FIGURE 1 - Classification of seriousness of medication errors according to the National Coordinating Council for Medication Error Reporting and Prevention (NCCMERP). 
filled out and signed a form indicating the Terms of Use for the Data, which aimed to preserve the privacy of the information contained in the reports.

\section{RESULTS AND DISCUSSION}

The sample included 165 error reports with similar number of occurrences for each year: 84 in 2010 and 81 in 2011. The reports were spontaneous and submitted by healthcare professionals from conventional inpatient units, intensive care units, and emergency units.

The seriousness of the reports showed that 114 reports were actual errors (medication errors) and 51 reports were categorized as potential errors. For 2010, 34 of the 84 reports $(40.48 \%)$ were evaluated as potential errors (category A). In 2011, 17 of the 81 reports (20.99\%) were classified as category A. There was a significant association between the year of report and category $\mathrm{A}$ reports $\left(\mathrm{X}^{2}=7.33 ; \mathrm{P}=0.007\right)$ (Table I).

A possible explanation for the decrease in potential error situations may be the educational efforts of the GUS. The aim of these efforts was to better inform HCPA professionals about medication error situations; they included events and direct efforts of improvement of the potential error situations reported.

The reports of circumstances or events potentially associated with errors are of great importance for the implementation of prevention measures. The Precautionary Principle (Jonas, 1994) states that the existence of risk of serious harm, or of irreversible harm requires the implementation of measures to predict the occurrence of the damage. The implementation of educational measures is a current and necessary proposition for hospitals. These measures are a way of safeguarding the legitimate interests of those (that is, every admitted patient and of the society as a whole) who may need hospital services. Healthcare professionals face a great challenge of recognizing the possibility of harm and the need to evaluate harm based on the knowledge available (Goldim, 2002).

Evaluation of the second criterion of seriousness showed that $109(66.06 \%)$ of the reports did not reach the patients (categories A and B), out of which 59 happened in 2010 and 50 in 2010. Comparison of the years 2010 and 2011 did not show a significant association between not reaching (categories $\mathrm{A}$ and $\mathrm{B}$ ) and reaching (categories $\mathrm{C}$ to I) the patient $\left(\mathrm{X}^{2}=1.33 ; \mathrm{P}>0.05\right)$ (Table 1$)$.

In 2010, the most frequent category was A (40.48\%); but in 2011, the most frequent category was B (40.74\%). The follow-up of reports during the two years showed that category B errors were the most frequently reported. In 2011 , there was a $5.21 \%$ increase in the error reports that reached the patient but did not cause harm. This result suggests that professionals already adopted the practice of reporting error situations, but may still have difficulties informing situations in which errors reached the patient. This difficulty may be caused by several reasons that have been reported in previous studies; the reasons include shame, guilt, and fear (Santos et al., 2007).

According to NCCMERP taxonomy (NCCMERP, $2001 \mathrm{~b}$ ), harm is defined as temporary or permanent impairment of the physical, emotional, or psychological function or structure of the body and/or pain resulting therefrom requiring intervention. All reports associated with harm resulted in temporary harm only (categories $\mathrm{E}$ and $F$ ). There were no reports involving permanent harm or fatal outcomes (categories G, H, and I) (Table I).

The results did not show a statistically significant association in relation to harm $\left(\mathrm{X}^{2}=0.06 ; \mathrm{P}>0.05\right)$. This result was obtained by the comparison of the categories that are not associated with harm (categories B, C, and D) with the categories that are associated with harm (categories E to I).

There was no significant association between the need to implement a measure (categories $\mathrm{E}$ to I) or at most monitor the patient (categories $\mathrm{B}$ to $\mathrm{D})\left(\mathrm{X}^{2}=0.06 ; \mathrm{P}>0.05\right)$. The necessary measures included medical intervention (category E), which occurred in $7.88 \%$ of reports, and prolonging hospital stay (category F), in $1.21 \%$ of cases.

In relation to seriousness, though there was an increase in medication error reports in 2011 in comparison to 2010 , there was no significant change in the profile of seriousness of these events. The results indicate, however, that educational measures that address medication errors are fostering the reports of more serious situations.

The NCCMERP Medication Error Index was proposed in 1996 and revised in 2001. Several authors advocate it is the most adequate method (Santell et al., 2003; Forrey et al., 2007). However, more data from different institutions need to be collected (in methodologically similar fashion) so that comparisons can be made with the data presently available (Lacasa et al., 2012; Menendez et al., 2012). We identified two Brazilian studies that applied this classification. One investigated prescription errors (Néri et al., 2011), and the other investigated errors in the preparation of intravenous medications (Camerini, Silva, 2011). However, the two studies do not provide the same comprehensive approach of the present study.

From a Bioethics standpoint, the classification of seriousness raises some issues. If harm was inflicted upon a patient due to medication error, there may be doubts among the healthcare team about the communication to the 
TABLE I - Seriousness classification for medication errors according to the National Coordinating Council for Medication Error Reporting and Prevention (NCCMERP), HCPA, 2010 - 2011 (N=165)

\begin{tabular}{lcccccc}
\hline Error category & $\mathrm{N}(2010)$ & $\operatorname{Fr}(\%)$ & $\mathrm{N}(2011)$ & $\operatorname{Fr}(\%)$ & Total (2010-1) & $\operatorname{Fr}(\%)$ \\
\hline $\mathrm{A}$ & 34 & 40.48 & 17 & 20.99 & 51 & 30.91 \\
$\mathrm{~B}$ & 25 & 29.76 & 33 & 40.74 & 58 & 35.15 \\
$\mathrm{C}$ & 6 & 7.14 & 10 & 12.35 & 16 & 9.7 \\
$\mathrm{D}$ & 12 & 14.29 & 13 & 16.05 & 25 & 15.15 \\
$\mathrm{E}$ & 7 & 8.33 & 6 & 7.41 & 13 & 7.88 \\
$\mathrm{~F}$ & 0 & 0 & 2 & 2.47 & 2 & 1.21 \\
$\mathrm{G}$ & 0 & 0 & 0 & 0 & 0 & 0 \\
$\mathrm{H}$ & 0 & 0 & 0 & 0 & 0 & 0 \\
I & 0 & 0 & 0 & 0 & 0 & 165 \\
\hline TOTAL & 84 & 100 & 81 & 100 & 100 \\
\hline
\end{tabular}

Notes: $\mathrm{N}=$ number of error reports $\mathrm{Fr}=$ percentage of error reports /total of error reports

patients or their relatives. The ethical issue is not whether to communicate or not, but rather how to communicate to the patient and relatives, and when. The patient medical records, which belong to the patient, report this type of situation. In this sense, the adequate report of an error helps to build a relationship of trust between patient and healthcare staff.

After exclusion of the situations classified as potential error (category A), we carried out the classification of type of medication error (categories B to I) according to the ASHP taxonomy. The type of medication errors may be classified from prescription errors to compliance to the treatment itself (Table II).

The most frequent type of medication error associated with the process was prescribing error: $48.25 \%$ of cases during the two years of the study. Most cases of prescribing error did not reach the patient because they were intercepted by the nursing staff. Prescribing errors involved ambiguous information, duplicate medications, and mistakes associated incorrect information in the computer system. Ambiguous information is identified when the prescription defines that the medication should be used "as necessary" or "according to medical orientation." Duplicate medications are identified when the same medication is included twice in the same prescription (at times with different dosages). Mistakes involving incorrect information are usually associated with units of measure, such as indicating milliliters instead of milligrams.

Electronic prescription of medication is internationally accepted as a tool that ensures safer use of medications; it reduces the medication error rates by facilitating the reading of the prescription (it avoids problems with understanding handwriting). However, if not used properly, electronic prescriptions may not help to ensure safer prescription of medications. The electronic prescription alone does not eliminate the possibility of medication errors (Koppel et al., 2005). The system adopted for electronic prescriptions should be constantly reevaluated.

Dispensing errors were reported only in 2010. A previous study developed in the HCPA (Almeida, 2010) indicated that the bar code reading system associated with changes in the infrastructure and work processes are the major factors behind the reduction in error rates for dispensing drugs in the hospital.

The frequency of spontaneous reports of errors of omission $(2.63 \%)$ and of wrong time error $(1.75 \%)$ was low. This suggests these cases may be underreported in the spontaneous reports. In studies that carried out direct observation of the medication administration stage, the errors of omission and of wrong time were above $10.0 \%$ and $8.0 \%$, respectively (Costa et al., 2006). These results corroborate Bohomol and Ramos (2007), who showed that professionals involved with the administration of medications do not consider omissions (which do reach the patient) an error. Similarly, these professionals characterize the wrong time in medication administration as a justifiable error due to the high number of patients attended or by the lack of sufficient medications.

The administration of non-authorized medications was reported in 13 events (11.40\%). In some of these situations the medication prescribed was administered to the wrong patient. This suggests that the first goal for patient safety (JCI, 2006), that is, the correct identification of patients, was not adequately met in these cases. 
TABLE II - Types of medication errors according to the American Society of Health-System Pharmacists (ASHP), HCPA, 2010 $2011(\mathrm{~N}=114)$

\begin{tabular}{|c|c|c|c|c|c|c|}
\hline Type of error & $\mathrm{N}(2010)$ & $\operatorname{Fr}(\%)$ & $\mathrm{N}(2011)$ & $\operatorname{Fr}(\%)$ & Total (2010-1) & $\operatorname{Fr}(\%)$ \\
\hline Prescribing & 24 & 48 & 31 & 48.44 & 55 & 48.25 \\
\hline Dispensing & 5 & 10 & 0 & 0 & 5 & 4.39 \\
\hline Omission & 2 & 4 & 1 & 1.56 & 3 & 2.63 \\
\hline Wrong time & 2 & 4 & 0 & 0 & 2 & 1.75 \\
\hline Unauthorized drug & 5 & 10 & 8 & 12.5 & 13 & 11.40 \\
\hline Improper dose & 5 & 10 & 8 & 12.5 & 13 & 11.40 \\
\hline Wrong dosage-form & 0 & 0 & 0 & 0 & 0 & 0 \\
\hline Wrong drug-preparation & 4 & 8 & 9 & 14.06 & 13 & 11.40 \\
\hline Wrong administration-technique & 3 & 6 & 5 & 7.81 & 8 & 7.02 \\
\hline Deteriorated drug & 0 & 0 & 0 & 0 & 0 & 0 \\
\hline Monitoring & 0 & 0 & 0 & 0 & 0 & 0 \\
\hline Compliance & 0 & 0 & 0 & 0 & 0 & 0 \\
\hline Other & 0 & 0 & 2 & 3.13 & 2 & 1.75 \\
\hline TOTAL & 50 & 100 & 64 & 100 & 114 & 100 \\
\hline
\end{tabular}

Notes: $\mathrm{N}=$ number of medication error reports $\mathrm{Fr}=$ percentage of medication error reports/total of medication error reports

Improper dose errors $(11.40 \%)$ were related to administration of drugs in doses higher or lower than prescribed, administration of an extra dose of the drug, and duplicate administration of a dose of the drug. They were mainly caused by poor understanding of prescriptions and failure of nursing staff to control the time of drug administration. In another Brazilian study (Teixeira, Cassiani, 2010), dose errors in drug administration were also among the three most common types of medication errors, accounting for $24.3 \%$ of medication errors related to drug doses administered differently than prescribed.

Thirteen events $(11.40 \%)$ were assessed as wrong drug-preparation errors and eight events $(7.02 \%)$ as wrong administration-technique errors. Miasso et al. (2006) analyzed the medication preparation and administration process in medical units at four Brazilian hospitals. Among the problems identified as contributing to the occurrence of medication errors, wrong drug-preparation errors and wrong administration-technique errors were observed in all hospitals.

Medication errors may generate additional associated errors, which occur exactly because there are successive actions, or actions that are associated with a chain of events. For example, there were prescribing errors and preparation errors that led to other errors associated with drug administration (omission error, improper dose error, wrong time error, and unauthorized drug error) in nine cases $(7.89 \%)$, out of which five $(10.0 \%)$ occurred in 2010 and four (6.25\%) in 2011.
The classification of type of medication error helps to identify which stages of the process of administering medications should be improved. In this sense, better communication between the professionals is a factor that deserves more attention. A culture of infallibility, which is present in the healthcare field, may lead to a lack of communication about mistakes between professionals. Spontaneous reporting may be inversely associated with the seriousness and the type of error that occur. Though it is a difficult task, it is necessary to separate errors caused by human error from errors caused by the system. The aim is not to find a culprit, but rather to establish personal and institutional accountability.

More than one medication may be included in the same error report. In the 114 reports there were 122 drugs cited, which were classified according to the ATC classification system (Table III) using only the first level of the classification, which groups drugs according to anatomical main group.

Drugs in code N (nervous system) were the most frequent medications associated with reports $(30.33 \%)$. For example, morphine and the antiepileptics carbamazepine and clonazepam are among the medications reported in the two years of study.

Code B drugs (blood and blood-forming organs) and code J drugs (anti-infectives for systemic use) were next in the reports; $15.57 \%$ and $14.75 \%$ frequency in the reports.

In 2011 there was a $12.31 \%$ increase in reports of category J medications. The reports included, for example, 
TABLE III - Drugs involved in medication error reports according to the Anatomical Therapeutic Chemical Classification System, HCPA, 2010 - $2011(\mathrm{~N}=122)$

\begin{tabular}{|c|c|c|c|c|c|c|}
\hline ATC level 1 & $\mathrm{~N}(2010)$ & $\operatorname{Fr}(\%)$ & $\mathrm{N}(2011)$ & $\operatorname{Fr}(\%)$ & Total $(2010-1)$ & $\operatorname{Fr}(\%)$ \\
\hline A-Alimentary tract and metabolism & 7 & 13.46 & 7 & 10 & 14 & 11.48 \\
\hline B - Blood and blood-forming organs & 9 & 17.31 & 10 & 14.29 & 19 & 15.57 \\
\hline $\mathrm{C}-$ Cardiovascular system & 5 & 9.62 & 4 & 5.71 & 9 & 7.38 \\
\hline D - Dermatologicals & 0 & 0 & 0 & 0 & 0 & 0 \\
\hline $\begin{array}{l}\mathrm{G}-\text { Genitourinary system and sex } \\
\text { hormones }\end{array}$ & 1 & 1.92 & 0 & 0 & 1 & 0.82 \\
\hline $\begin{array}{l}\mathrm{H} \text { - Systemic hormonal preparations, } \\
\text { excluding sex hormones and insulins }\end{array}$ & 0 & 0 & 3 & 4.29 & 3 & 2.46 \\
\hline $\mathrm{J}$ - Anti-infectives for systemic use & 4 & 7.69 & 14 & 20 & 18 & 14.75 \\
\hline $\begin{array}{l}\mathrm{L}-\text { Antineoplastic and } \\
\text { immunomodulating agents }\end{array}$ & 3 & 5.77 & 2 & 2.86 & 5 & 4.09 \\
\hline M-Musculoskeletal system & 1 & 1.92 & 2 & 2.86 & 3 & 2.46 \\
\hline $\mathrm{N}$ - Nervous system & 18 & 34.62 & 19 & 27.14 & 37 & 30.33 \\
\hline $\begin{array}{l}\mathrm{P}-\text { Antiparasitic products, insecticides } \\
\text { and repellents }\end{array}$ & 0 & 0 & 0 & 0 & 0 & 0 \\
\hline $\mathrm{R}$ - Respiratory system & 2 & 3.85 & 4 & 5.71 & 6 & 4.92 \\
\hline S - Sensory organs & 0 & 0 & 0 & 0 & 0 & 0 \\
\hline $\mathrm{V}-$ Various & 0 & 0 & 0 & 0 & 0 & 0 \\
\hline $\begin{array}{l}\text { Insufficient information for ATC } \\
\text { classification }\end{array}$ & 2 & 3.85 & 5 & 7.14 & 7 & 5.74 \\
\hline TOTAL & $52^{\mathrm{a}}$ & 100 & $70^{\mathrm{b}}$ & 100 & 122 & 100 \\
\hline
\end{tabular}

Notes: $\mathrm{N}=$ number of drugs cited in medication error reports $\mathrm{Fr}=$ percentage of drugs cited in medication error reports /total of drugs cited in medication error reports

${ }^{\mathrm{a}}$ In 2 reports more than one medication was cited. ${ }^{\mathrm{b}}$ In 6 reports more than one medication was cited.

the following antibacterial drugs in more than one occasion: metronidazole, meropenem, and clarithromycin.

A study carried out in the state of Goiás, Brazil (Silva et al., 2011) evaluated 230 reports from the nursing staff and that contained medication errors. The main drugs associated with errors were antineoplastic and immunomodulating agents (code L; 24.3\%), antiinfectives for systemic use (code J; 20.9\%), and blood and blood-forming organs (code B; 15.3\%).

High-alert medications such as NPH insulin (code A), regular insulin (code A), and enoxaparine (code B) were associated with several error reports. These medications have an inherent risk for harming patients if there is a mistake in the process of drug administration. The seriousness of the errors associated with these drugs is high; the drugs may lead to permanent or fatal outcomes (Rosa et al., 2009). The present study suggests that there is still room at the HCPA for improvement in the third international goal for patient safety, that is, improvement of high-alert medications safety. A previous study by
Franciscatto et al. (2011) had already reported the need to implement actions for improving this specific goal.

Once more, considering the classification of the medications involved in errors, patient medical records is an important document for evaluation and recording of information about prescription of medications and nursing reports of administration of the medication. Information about medication errors and about the medications themselves may be lost if not properly recorded. All healthcare professionals should be well-informed about the importance of recording possible errors and the drugs involved. The type of information necessary and the proper section for the description should be well-established. The report and recording of medication errors, including the description of the involved drug, ensure the monitoring of appropriate medication use.

In order to evaluate mistakes in the process of reporting medication errors, we also evaluated the reports of adverse drug reactions at the Pharmaceutical Service of the HCPA. There were only data for 2011. There were 12 
medication errors in 334 reports of adverse drug reactions. Eleven of these errors were code E, and one was code F. The types of error reported included prescribing errors, wrong drug-preparation error, and wrong administrationtechnique error. The drugs involved in adverse reaction reports included amphotericin $b$, with more than one occurrence, and vancomycin. The rate of adverse drug reactions mistakenly reported as medication errors was $3.59 \%$; all had associated harm. The occurrence of associated harm may have been a confounding factor in the reporting of medication errors as an adverse drug reaction.

Spontaneous reports of errors or potential error situations may help identify failures and weaknesses in the medication system in an Institution. If the spontaneous report system is well-structured and adequately managed, it may gradually ensure the participation of all collaborators in an Institution. As the data obtained from reports are converted into information through categorization and evaluation, a process of decision-making begins to take place. This process allows for actions to be carried out in the sense of correcting, whenever possible, these situations.

This study had some limitations regarding the quality of error reports. The voluntary reporting system at the HCPA was made available to staff at the end of 2009. Medication errors can be reported spontaneously through free text or standardized form. In most reports received during the study period the events were described by free text.Some reports did not have enough information for their correct categorization. Thus, the GUS meeting minutes were also used to search for additional information. Nevertheless, some reports (9) could not be used in the study.

\section{CONCLUSION}

Based on the results for the medication error reports in 2010 and 2011 at the HCPA:

A) In relation to seriousness, $30.91 \%$ of reports were about potential error (category A). In $60.0 \%$ of reports, medication errors did not reach the patient (category B) or reached the patient but did not cause harm (C and D). In the remaining reports, there was temporary harm associated (E and F); there were no reports associated with permanent harm or death $(\mathrm{G}$, $\mathrm{H}$, and I).

B) In relation to type of error, $48.25 \%$ of reports were associated with prescription. There were prescribing errors and preparation errors that led to other errors associated with drug administration in nine cases $(7.89 \%)$.
C) In relation to the drugs involved, including high-alert medications, there was a predominance $(60.65 \%)$ of medications for the nervous system (code N), blood and blood-forming organs (code B), and anti-infectives for systemic use (code J).

The reflection on medication errors and the possible harm that may ensue should follow a broad investigation of aspects involved in the occurrence of the error. The safety of patients depends on the process of communication of errors, on the adequate report and recording of information, and on the monitoring itself. All of these steps depend on the adequate understanding of the importance of each step, and on the compliance, on the part of all healthcare professionals.

The authors suggest that further research be conducted in order to study how the discussion of medication errors is flowing among professionals that act on the different stages of the medication system, seeking to verify the barriers and incentives that may prevent or encourage the reporting of medication errors.

\section{ACKNOWLEDGMENTS}

The authors would like to thank the GUS members for their availability and the student Frederico Maciel for the organization of the data collected.

\section{FINANCIAL SUPPORT}

The study received financial support from the Research and Events Incentive Fund (FIPE/HCPA).

\section{REFERENCES}

ALMEIDA, S.H.O. Incorporação de novas tecnologias de informação em um sistema de distribuição de medicamentos: avaliação quanto ao aumento da segurança de pacientes. Porto Alegre, 2010. 129 p. [Dissertion of master degree. Faculty of Pharmacy, Federal University of Rio Grande do Sul].

AMERICAN SOCIETY OF HOSPITAL PHARMACISTS. ASHP guidelines on preventing medication errors in hospitals. Am. J. Hosp. Pharm., v.50, n.2, p.305-314, 1993.

BOHOMOL, E.; RAMOS, L.H. Erro de medicação: importância da notificação no gerenciamento da segurança do paciente. Rev. Bras. Enferm., v.60, n.1, p.32-36, 2007. 
CAMERINI, F.G.; SILVA, L. Segurança do paciente: análise do preparo de medicação intravenosa em hospital da rede sentinela. Texto \& Contexto - Enferm., v.20, n.1, p.41-49, 2011.

CARVALHO, V.T.; CASSIANI, S.H.D.B. Erros na medicação e conseqüências para profissionais de enfermagem e clientes: um estudo exploratório. Rev. Latino-Am. Enfermagem, v.10, n.4, p.523-529, 2002.

COIMBRA, J.A.H. Prevenção e detecção de erros de medicação. Ciênc. Cuid. Saúde, v.5, suppl., p.142-148, 2006.

COLI, R.C.P.; ANJOS, M.F.; PEREIRA, L.L. The attitudes of nurses from an intensive care unit in the face of errors: an approach in light of bioethics. Rev. Latino-Am. Enfermagem, v.18, n.3, p.324-330, 2010.

COSTA, L.A.; LOUREIRO, S.; OLIVEIRA, M.G.G. Errores de medicación de dos hospitales de Brasil. Farm. Hosp., v.30, n.4, p.235-239, 2006.

FRANCISCATTO, L.; BESSOW, C.K.; RUZCZYK, J.V.A.; OLIVEIRA, M.A.; KLUCK, M.M. Metas internacionais de segurança do paciente em hospital universitário. Rev. HCPA, v.31, n.4, p.482-486, 2011.

FORREY, R.A.; PEDERSEN, C.A.; SCHNEIDER, P.J. Interrater agreement with a standard scheme for classifying medication errors. Am. J. Health Syst. Pharm., v.64, n.2, p.175-181, 2007.

GOLDIM, J.R. O princípio da precaução 2002. Available at: $<$ http://www.bioetica.ufrgs.br>. Accessed on: 06 Aug. 2012.

JOINT COMMISSION INTERNATIONAL. International patient safety goals created. Joint Commission Perspectives, v.26, n.2, p.8-8, 2006.

JONAS, H. Ética, medicina e técnica. 1.ed. Lisboa: Vega, 1994. 169 p.

KOPPEL, R.; METLAY, J.P.; COHEN, A.; ABALUCK B.; LOCALIO A.R.; KIMMEL S.E.; STROM B.L. Role of Computerized physician order entry systems in facilitating medication errors. JAMA, v.293, n.10, p.1197-1203, 2005.

LACASA, C.; AYESTARÁN, A. Estudio multicéntrico español para la prevención de errores de medicación. Resultados de cuatro años (2007-2011). Farm. Hosp., v.36, n.5, p.356-67, 2012.
MENENDEZ, M.D.; ALONSO, J.; RANCANO, I.; CORTE, J.J.; HERRANZ, V.; VAZQUEZ, F. Impact of computerized physician order entry on medication errors. Rev. Calid. Asist., v.27, n.6, p.334-340, 2012.

MIASSO, A.I.; SILVA, A.E.B.C.; CASSIANI, S.H.D.B.; GROU, C.R.; OLIVEIRA, R.C.; FAKIH, F.T. O processo de preparo e administração de medicamentos: identificação de problemas para propor melhorias e prevenir erros de medicação. Rev. Latino-Am. Enfermagem, v.14, n.3, p.354363, 2006.

NATIONALCOORDINATING COUNCILFOR MEDICATION ERROR REPORTING AND PREVENTION. About medication errors 2001a. Available at: $<$ http://www. nccmerp.org/medErrorCatIndex.html>. Accessed on: 06 Aug. 2012.

NATIONAL COORDINATING COUNCIL FOR MEDICATION ERROR REPORTING AND PREVENTION-NCCMERP. Index for categorizing medication errors 2001b. Available at: http://www.nccmerp. org/pdf/indexColor2001-06-12.pdf. Accessed on: 06 Aug. 2012.

NERI, E.D.R.; GADÊLHA, P.G.C.; MAIA, S.G.; PEREIRA, A.G.S.; ALMEIDA, P.C.; RODRIGUES, C.R.M.; PORTELA, M.P.; FONTELES, M.M.F. Erros de prescrição de medicamentos em um hospital brasileiro. Rev. Assoc. Med. Bras., v.57, n.3, p.306-314, 2011.

NUNES, P.H.C.; PEREIRA, B.M.G.; NOMINATO, J.C.S.; ALBUQUERQUE, E.M.; SILVA, L.F.N.; CASTRO, I.R.S.; CASTILHO, S. Intervenção farmacêutica e prevenção de eventos adversos. Rev. Bras. Ciênc. Farm., v.44, n.4, p.691-699, 2008.

OPTIZ, S.P. Sistema de medicação: análise dos erros nos processos de preparo e administração de medicamentos em um hospital de ensino. Ribeirão Preto, 2006. 190 p. [Thesis of PhD degree. School of Nursing of Ribeirão Preto, University of São Paulo].

OTERO, P.; LEYTON, A.; MARIANI, G.; CERNADAS, J.M.C. Medication errors in pediatric inpatients: prevalence and results of a prevention program. Pediatrics, v.122, n.3, p.737-743, 2008. 
RISSATO, M.A.R.; ROMANO-LIEBER, N.S.; LIEBER, R.R. Terminologia de incidentes com medicamentos no contexto hospitalar. Cad. Saúde Pública, v.24, n.9, p.1965-1975, 2008.

ROSA, M.B.; PERINI, E.; ANACLETO, T.A.; NEIVA, H.M.; BOGUTCHI, T. Erros na prescrição hospitalar de medicamentos potencialmente perigosos. Rev. Saúde Pública, v.43, n.3, p.490-498, 2009.

ROSA, M.B.; PERINI, E. Erros de medicação: quem foi? Rev. Assoc. Med. Bras., v.49, n.3, p.335-341, 2003.

SANTELL, J.P.; HICKS, R.W.; MCMEEKIN, J.; COUSINS, D.D. Medication errors: experience of the United States Pharmacopeia (USP) MEDMARX reporting system. $J$. Clin. Pharmacol., v.43, n.43, p.7, 2003.

SANTOS, J.O.; SILVA, A.E.B.C.; MUNARI, D.B.; MIASSO, A.I. Sentimentos de profissionais de enfermagem após a ocorrência de erros de medicação. Acta Paul. Enferm., v.20, n.4, p.483-488, 2007.

SILVA, A.E.B.C.; REIS, A.M.M.; MIASSO, A.I.; SANTOS, J.O.; CASSIANI, S.H.D.B. Adverse drug events in a sentinel hospital in the State of Goiás, Brazil. Rev. LatinoAm. Enfermagem, v.19, n.2, p.378-386, 2011.

TELLES FILHO, P.C.P.; PRAXEDES, M.F.S. Nursing journals and medication management: identification and categorization of publications from 1987 to 2008. Rev. Latino-Am. Enfermagem, v.17, n.5, p.721-729, 2009.
TEIXEIRA, T.C.A.; CASSIANI, S.H.D.B. Root cause analysis: evaluation of medication errors at a university hospital. Rev. Esc. Enferm. USP, v.44, n.1, p.139-146, 2010.

WANNMACHER, L. Erros: evitar o evitável. Brasília, junho de 2005. Available at: http://portal.saude.gov.br/portal/ arquivos/pdf/novo_erro_medico.pdf. Accessed on: 06 Aug. 2012.

WHO COLLABORATING CENTRE FOR DRUG STATISTICS METHODOLOGY. ATC/DDD Index 2012. Available at: http://www.whocc.no/atc_ddd_index/.Accssed on: 06 Aug. 2012.

WORLD HEALTH ORGANIZATION. International drug monitoring: the role of national centers. Genebra: OMS, 1972. 25p.

WORLD HEALTH ORGANIZATION. World alliance for patient safety: the conceptual framework for the international classification for patient safety version 1.1. Final technical report. January 2009. Available at: $<$ www. who.int/en/>. Accessed on: 06 Aug. 2012.

Received for publication on $12^{\text {th }}$ December 2012 Accepted for publication on $14^{\text {th }}$ May 2013 